\title{
IBM Manufacturing in the Nordic Countries
}

\author{
Petri Paju \\ Cultural History Department, University of Turku, Finland \\ petpaju@utu.fi
}

\begin{abstract}
Unlike other foreign computing companies, in addition to sales and service IBM early on also established production facilities in the Nordic countries. To provide a better understanding of the role of IBM in these countries, the article surveys IBM manufacturing in the region: what was produced, and where were these functions located? The term "production" is understood in a rather narrow sense, as manufacture. The results show that for several decades, IBM produced punched cards in four Nordic countries, but that after 1960 there has been only one IBM factory for hardware in the region, located in the Stockholm area. The article also discusses the reasons for Sweden's importance in IBM manufacture, and suggests that Nordic companies contributed to IBM manufacture through subcontracting.
\end{abstract}

Keywords: Computer history, hardware production, IBM World Trade Corporation, Nordic countries, punched card, subcontracting.

\section{Introduction}

From World War II to the 1980s, one of the most influential actors of the computer industry in the Nordic countries was IBM, the International Business Machines company. Throughout the period, this American multinational corporation was the data-processing market leader in all five countries belonging to the Nordic cultural region. Unlike many other foreign computer companies, in addition to sales and service IBM early on also established production facilities in the Nordic countries. IBM's wide international connections had many implications for national developments, from Iceland to Finland. As in many other parts of the world, IBM was or became a contested player in Scandinavia too, no doubt partly because of its formidable size and dominance. According to some current beliefs, IBM was often perceived as, or argued to be, a counter-force to the national computer industries. To understand better the role of IBM in the Nordic area, this article discusses IBM manufacturing in the Nordic countries.

Some parts of IBM production in the Nordic area may be well known, but not the whole or big picture. In the book History of Nordic Computing, Hans Andersin wrote about IBM's role in the early development of computing in the Nordic countries. A recent study has argued that IBM's success in Europe was partly due to its production structure, which was organized in terms of the whole continent [1, 2]. IBM has 
usually been dealt with on a national basis, although IBM itself was comprised of several levels and perspectives, national as well as multinational. During most of the period covered in this article the Nordic IBM subsidiaries were part of the IBM World Trade Corporation; this organization did business everywhere except in the United States, where IBM sales were managed by the IBM Corporation.

In the article, I ask the following questions: What did IBM produce in the Nordic area? Where were these functions located? The term "production" is understood in a rather narrow sense, as manufacture, i.e. mainly plants that produce things. Other productive activities, such as training and software writing, are thus excluded. A further question is, did the Nordic IBM plants in turn make a special contribution within IBM?

To some extent, this article contributes to the discussion of the effect of these operations, including their possible influence on the national information technology industries in these countries. In addition, it provides information - although indirectly - on IBM's customers and computer users and their concentrations in the region.

The paper is based on a varied array of material and literature. I have used some archival sources from the IBM Corporation in the USA and from IBM Finland, as well as IBM publications, including IBM's internal staff magazines. For the most part, however, my main sources consist of the secondary literature, such as academic studies. ${ }^{1}$ The article is part of a larger, ongoing research project, which examines the co-shaping of computer expertise in Europe in the Cold War era, and visions of European capabilities, using IBM technology. To grasp the long evolution of IBM's manufacturing in the Nordic area, I need to start from the state of data processing before the computer [3].

\section{IBM Enters the Nordic Countries}

The first national IBM subsidiary in the Nordic area was established in Sweden, in 1928. At the time, however, IBM had already had sales agents in most Nordic countries for several years. The first IBM or Hollerith machines had been delivered even earlier. In fact, in 1894 Norway became one of the earliest countries outside the United States to test the punched card machines developed (for purposes of census tabulation) by Herman Hollerith in the 1880s [4]. In 1911, Hollerith's technology became a key product for the company that was renamed IBM in 1924. Soon afterwards, IBM founded its first factories in Europe, located in France and Germany.

The Nordic national IBM companies were founded in the period from 1928 to 1967 (see Table 1). These dates, and their order, may have played a role when IBM management chose locations for IBM facilities, so they merit some attention. The Swedish subsidiary was established first, and evidently became an administrative centre for IBM's expansion in the region. This history probably offers some explanation for the large part that Sweden would play in further IBM development in the Nordic region.

\footnotetext{
${ }^{1}$ See also the article by Eric Malmi, Timo Honkela and myself, in this volume.
} 
Table 1. The Establishing of Nordic IBM Country Organizations

\begin{tabular}{|l|l|l|}
\hline Year & Country & Organization type \\
\hline 1928 & Sweden & Subsidiary \\
\hline 1935 & Norway & Subsidiary \\
\hline 1936 & Finland & Subsidiary \\
\hline 1950 & Denmark & Subsidiary \\
\hline 1967 & Iceland & Branch Office \\
\hline
\end{tabular}

The Danish agent was evidently doing so well that IBM waited until the late 1940s to push for a national subsidiary there. From 1950 onward, when the IBM World Trade Corporation (WTC) was established, this new company, with its global reach, included a newly formed IBM subsidiary in Denmark. In Iceland, prior to 1967, IBM had had a national representative from 1948, coordinated from Denmark. In Reykjavik, the Icelandic capital, IBM punched card machines were first introduced in $1949[5] .^{2}$

\section{Punched Card Production}

IBM started production in the Nordic countries in 1932, with the manufacture of punched cards. Unsurprisingly, it was Swedish IBM that was involved, since it was the only IBM Company in the region. In 1932 the Swedish IBM company build a Carroll Press, named after its designer, the IBM engineer Fred Carroll. In the first year, eighteen million cards were printed. The punched card plant moved to Vällingby in 1954. Punched card printing peaked in 1969, when the factory in Sweden produced one billion cards. Card manufacture ended in Sweden in 1980 [6]. In other words, IBM Sweden was printing punched cards for almost fifty years.

Although often unappreciated as a key part of data processing in its time, punched cards were of crucial importance to the data processing business and to IBM. The cards themselves were used in most things IBM and its customers did, but especially in large-scale data processing; for a considerable time, nothing could be done without those actual pieces of special paper. For IBM, moreover, the cards had been a highly profitable and steady source of income already in the 1930s, and they continued to give the company financial stability $[3,7]$. Thus, a significant part of IBM's business was the production and delivery of punched cards.

IBM punched cards needed in Finland, for instance, were first shipped from Germany and later from Sweden. In Helsinki, the first Hollerith cards had been ordered by the Statistical head office in 1922. After 1932, with the inception of the Swedish plant, punched cards for the Finnish IBM agent and later for the IBM subsidiary (est. 1936), as well as for customers, were probably supplied by IBM Sweden [8].

The period of World War II brought a wave of IBM production to the Nordic countries. This was probably because of difficulties with IBM punched card

${ }^{2}$ For a history of the IBM branch office in Iceland, see Sverrir Olafsson's article in this volume. For information on the Danish IBM agent and early IBM business in Denmark, see Søren Duus Østergaard's article in this volume. 
deliveries. Between 1940 and 1943, punched card plants were established in Norway (1940), Finland (1942) and Denmark (1943), although the Danish plant was owned by the national IBM agent [8-10]. It seems remarkable that IBM Sweden was able to help both the Danish IBM agent and IBM Finland in establishing card plants, considering that Finland was in a state of war and Denmark was occupied by German troops [8]. ${ }^{3}$ Nevertheless, along with eventual assistance from IBM Sweden this period reveals some tension and competition among the IBM companies.

For the Finnish subsidiary, securing a punched card factory was not all that straightforward. As mentioned, in the late 1930s IBM Finland received its punched cards from Sweden. In wartime, these deliveries could not be guaranteed, and IBM Finland came up with the idea of producing its own punched cards. The CEO of IBM in Finland, Einar Dickman, visited IBM Sweden's card plant in August 1940, during the interval of peace in Finland between the Winter War of 1939-1940 and the Continuation War, which began in the summer of 1941. (Sweden of course maintained neutrality during World War II.) Dickman calculated that if Finnish IBM made its own cards, one of the printing machines in Sweden would became idle and could be moved to Finland. He suggested this to the European headquarters, but IBM Sweden did not agree; they said they needed all of their machines. In 1942, however, a used printing machine was imported from IBM Sweden to Helsinki, where a Finnish IBM punched card factory operated during 1942-1946 [8, 11].

During the war, IBM Finland also received some help from IBM Sweden and IBM Norway. In addition to spare parts, they occasionally sent engineers for service tasks while Finnish engineers were at the front or otherwise serving the war effort [12]. ${ }^{4}$ Help was also sought from a Polish expert, but apparently, the Germans wanted to keep him [11].

In using punched cards and in IBM's business with them, the most important thing was card quality: not only in a general sense, but more specifically because bad card quality made the machines jam and IBM service had to fix them. Since the IBM machines were rented to the customers, service meant extra costs for IBM. The need to minimize costs made card quality so essential for business.

The importance of card quality is indicated by the fact that in 1946 IBM Finland again started importing cards from Sweden; the old printing press in Helsinki could no longer produce cards of sufficient quality. Moreover, because of the growing postwar demand the Swedish subsidiary could not deliver cards for Finland in sufficient quantity. The Finns therefore applied to the World Trade Division in New York for a new printing machine to be placed in Finland $[8,11] .^{5}$ It is clear that the Swedish and Finnish IBM companies had different interests in card production. The national subsidiaries negotiated over this question with and through IBM headquarters. Within the multinational company, this certainly exemplifies international competition over company facilities and functions. Such negotiations among IBM nationals may have also reinforced the parties' national feelings.

\footnotetext{
${ }^{3}$ For the card plant's situation in Denmark, see Søren Duus Østergaard's article in this volume.

${ }^{4}$ Cf. According to Anttila [11] it was often difficult to get that (or any) help. Anttila had access to the original correspondence, which is now missing.

5 The IBM World Trade Division was the form of organization in 1947, right before the establishment of the World Trade Corporation.
} 
Finally, in 1952, an IBM punched card factory (re)opened in Helsinki. The card plant began production despite difficulties in the first years. The greatest problems were in meeting the high standards that were required for functional paper cards. The paper for the cards was manufactured by and bought from a medium-sized Finnish pulp and paper company, the G. A. Serlachius factory at Kangas, near Jyväskylä [8]. IBM card manufacture continued in Finland until the late 1970s, for twenty-six years. All this was certainly an important argument for the IBM Finland's national significance.

In the 1960s, the same Finnish pulp and paper company started selling and exporting its material to foreign IBM subsidiaries as well. Finnish IBM printed cards for Finland, but it also exported them to other IBM subsidiaries. Interestingly, in the mid-1970s the Finnish subsidiary, as a subcontractor, also exported cards to the Soviet Union [13]. These were most probably delivered to the IBM operation coordinated from Moscow.

One consequence of the punched card press and related technology transfer to Finland was that the manager of the IBM press, Ulf Enbom, resigned from IBM in 1957 and started a card plant of his own in 1958. He co-developed new machinery for card printing and competed with IBM Finland by producing punched cards. In the 1960s, however, the new company could not compete and had to close down [14].

In 1950, when the Danish IBM subsidiary was established, it also took over the punched card press there. In 1970, 70 percent of all Danish computer systems used punched cards as their input medium. At the time, card production was mostly carried out within the country and accounted for some one billion cards [9]. Thus IBM Denmark, the clear market leader, continued to produce cards there at least well into the seventies. In Norway the peak of IBM's punched card production, six hundred million cards a year, was achieved in 1970, a year later than in Sweden, indicating the long-lasting demand for the cards [15].

For all these national plants, quality control and testing were essential. In these respects, IBM's international network of transnational resources played a major role in the manufacture of cards and other "information record" devices. In the Finnish case, tests were performed by the Finnish subcontractor and by an IBM print technology laboratory in Stockholm. Another IBM laboratory, located in Sindelfingen, West-Germany, tested the color ingredients for the color tapes (used in IBM typewriters). There were also several other IBM units involved, although not in dealing with punched cards [16]. In other words, the international IBM network made a big difference for national card production sites as well. Evidently, most of these IBM laboratories served all of the IBM card plants in Europe. This made the plants' available transnational IBM resources hard to compete with by means of national resources alone - particularly with regard to card quality.

\section{Hardware Manufacturing}

In addition to punched cards, other IBM manufacturing in the Nordic area started properly in the early 1950s in Sweden and Norway. In his compilation of information on national IBM history in Europe in the late 1960s, James Connolly mentions that IBM Sweden produced its first hand key punches already in 1941 [17]. It was in 1951, 
however, that IBM commenced assembling electric typewriters in Stockholm (at Norra Stationsgatan). Two years later, in 1953, the Stockholm factory produced its thousandth electric typewriter. These typewriters were made in Sweden until 1961 $[10,18]$, when other production in Sweden was expanded.

In 1952, IBM Norway started producing time recorders. In the late 1950s, IBM Norway also manufactured electric typewriters for a few years [15]. By 1959, the Oslo Plant had produced its five thousandth IBM 780 job cost and attendance time recorder [10]. ${ }^{6}$ Production in Oslo continued until 1960, when it was moved to other countries as IBM reorganized or cut its manufacturing [15]. In 1964, IBM World Trade ended its time recorder business altogether [10].

In 1954, all IBM manufacturing in Sweden was concentrated at a new factory in Vällingby, in the Stockholm area. At the new premises IBM workers printed punch cards, assembled electronic typewriters and punched-card machines, and made time recorders. [6] The punch card machines produced were the IBM 082 sorter, the IBM 416 tabulator and the IBM 513 reproducer. ${ }^{7}$ Initially the factory employed 120 people [10].

Tellingly of Sweden's modernization in city planning, and of IBM's place in this development, Vällingby, the location of the IBM factory complex, was the first "town of the future." It was an "ABC City" — an acronym for "Arbete-Bostad-Centrum," or "work and residential center" - a suburb designed to offer its residents everything they needed, similar to an independent city. It was inaugurated in 1954, the same year IBM moved in [19]. The new city and its architecture attracted public attention in Sweden and even internationally.

In 1961 IBM enlarged the Vällingby factory, although they also stopped producing typewriters the same year [10]. The expansion was needed for the manufacturing of new products. In 1960 the factory had commenced the production of two new punched card machines, the IBM 088 and the IBM 1402. The IBM 088 was a collator, a machine that shuffled separate decks or card piles together into one or more decks $[17,20]$. The IBM 1402 was a card reader punch, originally designed as part of the IBM 1401 data processing system. In 1967, the plant began manufacturing another peripheral for the IBM 1401 computer, the IBM 1403 printer [10].

The IBM 1401 was the first transistorized computer system for smaller businesses, which could continue using the punched cards and get a computer relatively cheaply. The 1401 system was announced in 1959 and became IBM's breakthrough model in computers until its withdrawal in 1971 [7, 21], see also [2]. With the peripheral machines, which were integral to the computer system - the IBM 1402 and especially the printer IBM 1403 - production in Sweden contributed to and shared in IBM's worldwide success.

\section{The IBM Factory in Sweden Focuses on Printers}

Thanks to its fast-growing sales, IBM erected a new factory at Järfälla (or Jarfalla, the form used in English) in 1970. The Järfälla municipality, like Vällingby, is located in

${ }^{6}$ Cf. Nerheim \& Nordvik [15], who give 1957 as the year of the five thousandth IBM 780.

7 The factory's products changed from time to time. The products listed in this article were the main items produced, but the list is not comprehensive. 
the greater Stockholm area. In fact, the new factory site was located only a few kilometers from the older site at Vällingby [22]. With the exception of the punched card plant, which remained in Vällingby until its closure in 1980 [18], all IBM manufacture in Sweden was relocated to the Järfälla premises.

Already in 1970, the factory was making printers for all of Europe. During the seventies, several new printers went into production in Järfälla. After the introduction of the IBM system 370 in 1970, for instance, came the IBM 3211 line printer. In 1976, the Järfälla plant shipped its first IBM 3800 laser printers [10]. Most of the production at the factory was for export [18].

According to information provided at an international press conference at Järfälla in 1971, 95 percent of products were exported to 108 IBM countries. Out of about 3,300 IBM employees in Sweden, a little over 1,000 worked at the factory. This manufacturing supported a large number of subcontractors from several countries [23].

Printers had become the target area for Swedish IBM production. It may be relevant here that the Swedish company Facit had been highly regarded, by IBM executives among others, for its peripheral devices. In late 1958 the top management of IBM World Trade met with Facit executives at the IBM World Trade Corporation's New York headquarters; IBM expressed ample interest in co-operation with Facit, especially because of the latter's expertise in peripherals, including printers. However, soon afterwards, in 1959, IBM suddenly withdrew from these plans and continued as competitively as ever [24].

In this focus on printers, it is possible that IBM was impacted by Swedish knowhow, leading IBM World Trade to choose to focus on printer production at its Swedish factory. In Sweden, IBM might be able to hire printer specialists from or around Facit, or at least to weaken Facit's competitive status in manufacturing, by this production decision and the related hiring and subcontracting.

\section{Subcontracting for IBM's European Plants}

Most of the Nordic countries contributed some subcontractors to IBM's manufacturing in Europe. In Finland, for instance, subcontracting via IBM Finland started in the early 1960s, when several foreign IBM subsidiaries began ordering the custom-made stiff paper for their punched cards from the same supplier, the Serlachius pulp and paper company, that had been supplying the Finnish IBM card factory since 1952 [25].

Importantly, subcontracting was apparently one thing the IBM subsidiary could increase in response to the criticism that IBM's business consisted too much of just importing hardware and software to Finland. This debate and the subsequent actions (on both sides) were part of a larger European response to the debate over the American challenge in the late 1960s. The debate of the late 1960s and early 1970s included the 1967 book Le Défi Américain, by Jean-Jacques Servan-Schreiber. The next year the book was published in English as The American Challenge, as well as in Swedish and Finnish translations; the Finnish title was Dollarin maihinnousu (Invasion of the Dollar, 1968). A similar debate, and the IBM reaction, especially in the form of increasing subcontracting, was going on in all the Nordic countries; in 
fact, the only Nordic country with no subcontractors for IBM plants was Iceland. Subcontracting possibilities were in fact seriously investigated in Reykjavik too, but no business justification could be found [26].

IBM Finland appointed a coordinator for subcontracting in 1970. He reported both to the European Purchasing Competence Center (EPCC) which coordinated subcontractors in Europe and IBM's European Plants, and to the CEO of IBM Finland [27]. In the late 1960s, the price level in Finland was low by international standards, making the country more attractive for IBM buyers [25]. Just as IBM production was organized continentally, so evidently was subcontracting as part of IBM production structures.

Already in 1971, the value of Finnish subcontractors' deliveries to foreign IBM companies equaled thirty to 40 percent of IBM Finland's imports, and the figure was expected to grow during the seventies. In 1976, some twenty companies in Finland made products for IBM companies in Europe. These deliveries secured around two hundred jobs annually $[25,28]$. Three years later IBM estimated this figure at 250 jobs. In the 1980s, a significant producer for IBM's personal computers was the large Finnish consumer electronics company Salora, later merged with Nokia, which delivered monitors to an IBM factory in Italy $[29,30] .^{8}$

In Norway, there were some twenty subcontractors in 1985 delivering to IBM's European factories [15]. In addition to subcontracts, actual production could also be transnational or trans-border, when for instance in 1983 a Danish subcontractor was chosen to manufacture the new IBM 4250 printer in support of the IBM plant at Järfälla, Sweden [10].

On the demand or IBM side, the Järfälla plant, as the one Nordic IBM factory, was by far the biggest IBM customer for subcontractors in the Nordic countries. In 1971, the new factory utilized approximately five hundred subcontractors [23]. Out of this significant number of businesses, presumably many were from Sweden and the other Nordic countries.

By its choice of subcontractors, the IBM World Trade Corporation benefitted from the strengths of individual companies in the Nordic countries; and perhaps vice versa, the Nordic companies had an impact on IBM products. The supplier and product examples above represented the contributions to and involvement in IBM's European production system of Finnish, Norwegian and Danish subcontractors.

\section{IBM and Other Production}

What about other computer vendors - did they produce something similar in the Nordic region? One of IBM's rivals, the (French) Bull Company originated in Norway; but the construction of Bull punched card machines was relocated to France already in 1931 [4]. By 1967, Burroughs had a demonstration centre in Sweden, but no actual manufacture in Scandinavia [17]. It was mostly Nordic, more specifically Swedish and later Finnish (Nokia) computer companies that maintained production facilities in several Nordic countries. Compared to other major computer companies, IBM was clearly the one most involved in computing-related production in the Nordic countries.

${ }^{8}$ The Salora Company also manufactured monitors for several other computer companies [30]. 
However, IBM not only produced things in the Nordic countries, but also the reverse: it sought to undo or to discourage competition. According to Hans Andersin, who was at IBM Finland, and on two assignments in Sweden, all during 1956-1965, IBM headquarters (IBM World Trade Corporation HQ in New York, presumably) had specialists whose job it was to prevent the establishment of national computer industries, obviously also in the Nordic countries. They offered cooperation and subcontracting agreements and/or advised against competing with IBM. IBM, for instance, tried - unsuccessfully - to discourage the Finnish Cable Factory, later Nokia, from embarking on the computer business in the early 1960s [1].

\section{Discussing the Bigger Picture}

In this article, I have addressed the question of IBM manufacturing in the Nordic countries before the 1990s. Previously, the stories of IBM subsidiaries in Scandinavia have been framed primarily in national terms. I hope to have shown that a wider, international Nordic perspective brings significant benefits for understanding IBM in each of the Nordic countries. Further, the picture of IBM production structures has become considerably clearer.

On the one hand, the printing of punched cards started early on in Sweden and spread, in the war time and soon after, to all four Nordic subsidiaries (see Table 2). In punched card manufacture, all the subsidiaries took part in IBM's transnational coordination and co-operation structures. The only exception in the region was the IBM branch office in Iceland, which was less independent than a national subsidiary and had no IBM manufacture; it merely imported punched cards from the USA [26].

The four IBM card plants in the Nordic countries serve as a reminder of the great importance of punched cards to the data-processing business. For a considerable time, at least half a century, punched cards were essential for most IBM data processing. Millions and millions of those precisely shaped pieces of special paper were used in most of the activities of IBM subsidiaries - activities consisting of sales and services, which have mostly been ignored in this article. In these operations, IBM personnel made most of their contacts with customers and computer users. A major reason for establishing and maintaining IBM punched card plants in the four Nordic countries was no doubt the proximity to customers, giving easy accessibility and minimizing transportation costs. This was one way in which Nordic IBM customers indirectly influenced and benefitted from IBM activities in the region and from their location.

The distribution of other manufacturing was much more uneven. As IBM's production system was European, the Nordic region did not form a coherent unit in the system but was integrated into the larger production network. Clearly, Sweden was the big player in IBM manufacture among the Nordic country organizations and locations (see Table 2). Within the Nordic region, the most significant hub of IBM production developed in the Stockholm area. In the 1950s, other manufacture was temporarily located in Norway. From 1960 onwards, the only IBM manufacturing site for hardware in the Nordic countries was IBM's Swedish factory. 
Table 2. New IBM Plants \& Location by Country in the Nordic region up to the 1990s

\begin{tabular}{|c|c|c|c|c|c|c|}
\hline IBM & $1930 \mathrm{~s}$ & $1940 \mathrm{~s}$ & $1950 \mathrm{~s}$ & $1960 \mathrm{~s}$ & $1970 \mathrm{~s}$ & $1980 \mathrm{~s}$ \\
\hline Sweden & $\begin{array}{l}\text { Punched- } \\
\text { card (P- } \\
\text { C) press }\end{array}$ & & $\begin{array}{l}\text { Factory, misc. } \\
\text { products; } \\
\text { typewriters, } \\
\text { punched card } \\
\text { machines }\end{array}$ & $\begin{array}{l}\text { New } \\
\text { products, } \\
\text { printers }\end{array}$ & $\begin{array}{l}\text { New Järfälla site, } \\
\text { manufacturing } \\
\text { printers for } \\
\text { Europe }\end{array}$ & $\begin{array}{l}\text { P-C } \\
\text { Press } \\
\text { closed } \\
(-80)\end{array}$ \\
\hline Norway & & $\begin{array}{l}\text { P-C } \\
\text { Press }\end{array}$ & $\begin{array}{l}\text { Factory, esp. } \\
\text { time recorder } \\
\text { production } \\
\text { (until -60) }\end{array}$ & & & \\
\hline Finland & & $\begin{array}{l}\text { P-C } \\
\text { Press }) \\
\end{array}$ & P-C Press & & $\begin{array}{l}\text { Subcontracting, } \\
\text { P-C Press closed }\end{array}$ & \\
\hline Denmark & & $\begin{array}{l}\text { Agent: } \\
\text { P-C } \\
\text { Press }\end{array}$ & P-C Press & & & \\
\hline Iceland & & & & $\begin{array}{l}\text { est. } 1967 \\
\text { as an IBM } \\
\text { Branch } \\
\text { Office }\end{array}$ & & \\
\hline & & & & & $\begin{array}{l}\text { All but Iceland: } \\
\text { Subcontracts }\end{array}$ & \\
\hline
\end{tabular}

There were probably numerous reasons why Sweden, industrially the most advanced and successful of the Nordic countries, became the location of so much IBM manufacture. An excellent explanation is offered by the national computer markets: the first IBM computers in the Nordic region were installed in Sweden in 1956. ${ }^{9}$ According to the World computer census in December 1966, the number of computers in the Scandinavian countries was (roughly, at least) as follows [32]: ${ }^{10}$

$\begin{array}{lr}\text { Sweden } & 350 \\ \text { Denmark } & 175 \\ \text { Norway } & 150 \\ \text { Finland } & 90 \\ \text { Iceland } & 3\end{array}$

Clearly, Sweden was the earliest and biggest national market, in digital computers too, in the Nordic countries. However, it also had the toughest competition. Among the Nordic countries, it was Swedish professionals who had the highest hopes for a successful national computer company; this meant that IBM was also heavily criticized, especially when the Swedish companies could not sustain the competition, see $[24,33]$. Perhaps this competitive situation contributed to the fact that Sweden was able to attract a lot of IBM functions and operations.

Until the mid-1960s most of both national Swedish IBM facilities and international Nordic IBM operations were located in or around the Swedish capital [34]; later

9 The first IBM computers followed in Norway (1958), Finland (1958; also the first computer in the country), Denmark (1959), and Iceland (1964; the first computer in the country) [1]. See also [31].

${ }^{10}$ Iceland was not included in this census source. Its figure is based on [26]. 
Copenhagen started gaining IBM functions, see [1,9]. To a perhaps significant level, IBM companies could also be national and even nationalist in competing for the allocation of IBM operations. This question too requires further study.

Was there some specifically Nordic contribution to IBM? One such area was probably the focus of IBM's Swedish manufacturing plant on peripherals and especially on printers from the mid-1960s onward. Eventually, Sweden provided printers for IBM in all of Europe. In each Nordic nation, subcontracts to IBM's European plants were another instance where the national Nordic companies could use their individual strengths and capacity.

\section{Conclusion}

Unlike any of its major competitors, IBM early on established manufacturing facilities in the Nordic region. These IBM activities have received limited attention, but they may offer a tool both for a better understanding of IBM in the Nordic region and for exploring Nordic contributions to IBM. For decades, IBM produced punched cards in four Nordic countries, whereas after 1960 there was one IBM hardware factory in the region, located in the Stockholm area. For several reasons, discussed above, IBM concentrated its Nordic hardware manufacturing in Sweden. There (and elsewhere in Europe), companies from four Nordic countries contributed to IBM manufacture through subcontracting. In addition, the IBM factory in Sweden specialized in printer production, which probably included local contributions. Studying those contributions requires further evidence and scrutiny.

Overall, IBM may perhaps have been more Nordic than most of its competitors, including those which were Nordic themselves. By Nordic, I mean here that some manufacturing was performed in most of the Nordic countries (as opposed to being done in one, two or three of them), and that IBM cooperation among the Nordic countries was inclusive, usually including all or most of its Nordic organizations. Moreover, the findings presented in this article suggest that IBM manufacturing in the Nordic countries was linked to its success in the region; the relationship between economic success and manufacturing, however, calls for further research.

Furthermore, IBM involved Nordic IBM staff in building its international and transnational operations models. Meanwhile, IBM itself was influenced by and incorporated the contributions of its Nordic subsidiaries. The precise nature of this influence in each individual national environment remains to be examined: what did it mean for their information technology industries? How and why the international patterns of operations of the Nordic IBM companies evolve as they did? More Nordic cooperation and contributions can be uncovered by studying IBM education and R\&D work in the region [14]. Perhaps studying IBM's operation pattern in the Nordic region can help us to understand how IBM operated in other regions as well.

Finally, the ending of the Cold War division of Europe around 1990 brought many changes for IBM manufacturing in the Nordic countries. In 1989, the Järfälla plant became a subcontractor to an independent LexMark Company owned by IBM. Two years later IBM sold this part of its business, including printer production, to another American company. In 1994 IBM sold its majority share of the Järfälla plant [18], see also [11]. 
Today, a reorganized IBM continues its operation in the Nordic area, but its manufacturing has moved on. What remains are memories of it and probably some influence on the information technology industries in the Nordic countries.

Acknowledgments. This research project started as part of the European Science Foundation EUROCORES Research program, "Inventing Europe: Technology and the Making of Europe, 1850 to the Present," and has benefitted from its collaborative research project, Software for Europe. My part of it has been funded by the Academy of Finland. Thanks are due to the staff at the IBM Archive and to James Cortada.

\section{References}

1. Andersin, H.E.: The role of IBM in starting up computing in the Nordic countries. In: Bubenko Jr., J., Impagliazzo, J., Sølvberg, A. (eds.) History of Nordic Computing, pp. 3343. Springer, New York (2005)

2. Schlombs, C.: Engineering International Expansion: IBM and Remington Rand in European Computer Markets. IEEE Annals of the History of Computing 30(4), 42-58 (2008)

3. Cortada, J.W.: Before the Computer. IBM, NCR, Burroughs, and Remington Rand and the industry they created 1865-1956. Princeton university press, Princeton (1993)

4. Heide, L.: Punched-Card Systems and the Early Information Explosion, 1880-1945. The Johns Hopkins University Press, Baltimore (2009)

5. Kjartansson, Ó.: Data Processing with Unit Record Equipment in Iceland. In: Impagliazzo, J., Järvi, T., Paju, P. (eds.) History of Nordic Computing 2. IFIP AICT, vol. 303, pp. 225229. Springer, Berlin (2009)

6. Hallberg, T.J.: IT gryning. Svensk datahistoria från 1840- till 1960-talet. Studentlitteratur, Lund (2007)

7. Campbell-Kelly, M., Aspray, W.: Computer. A History of the Information Machine. Basic books, New York (1996)

8. Dickman, E.: Några data beträffande förhållandena på hålkorts-området i Finland före 1937 (and other parts). Av Einar Dickman, antecknade - huvudsakligen - ur minnet under (December 1961 - January 1962) (Some facts about conditions in the punched card field in Finland prior to 1937. In Swedish) Manuscript, located at the IBM Finland Archive (unpublished)

9. Heide, L.: Hulkort og EDB i Danmark 1911-1970. Forlaget Systime A/S, Århus (1996)

10. Sayers, K.W.: A Summary History of IBM's International Operations 1911-2006, IBM 2006., 2nd edn. IBM Archive. Somers, New York (2006)

11. Anttila, P.: Big Blue Suomessa. O. y. International Business Machines A. b. 1936-1996. (Big Blue in Finland. O. y. International Business Machines A. b. 1936-1996, in Finnish). Published by the author, printed in Salo (1997)

12. Dickman, K.: Uudet tuotteet - tuttu ympäristö (New products - familiar environment, in Finnish). In: Tienari, M. (ed.) Tietotekniikan alkuvuodet Suomessa (The first years of information technology in Finland, in Finnish.), Suomen Atk-kustannus Oy, Helsinki, pp. 316-339 (1993)

13. Nuutila, T.: Suomen IBM:n atk-tarvikeosasto tänään (IBM Finland's information records division today, in Finnish.) IBM Katsaus 15(3), 46-47 (1976) 
14. Paju, P.: The many levels of IBM operations in Europe. Combining national and transnational in IBM Finland. In: Alberts, G., Durnová, H., Nofre, D., Paju, P., Sumner, J. (eds.) Computing in many languages. European practices and identities in the early Cold War era (2011) (forthcoming)

15. Nerheim, G., Nordvik, H. W.: Ikke bara maskiner. Historien om IBM i Norge 1935-1985. Universitetsforlaget, Oslo (1986)

16. Tietoa kortilla - jos nauhoillakin. Suomen IBM:n ATK-tarvikeosasto, IRD, Information Records Division (Information on card - and also on tapes. IBM Finland's Information Records Division, in Finnish). IBM Katsaus 10(2), 42-45 (1971)

17. Connolly, J.: History of Computing in Europe. IBM World Trade Corporation, New York (1967)

18. IBM Svenska ABs historia,

http://www-05.ibm.com/se/ibm/sweden/history/ (accessed May 25, 2010)

19. Johansson, I.: Stor-Stockholms bebyggelsehistoria. Markpolitik, planering och byggande under sju sekler. Gidlunds, Stockholm (1987)

20. It happened in Sweden. IBM World Trade News, 13 (12), 5 (1961)

21. IBM Archives,

http: / / www-03.ibm.com/ibm/history/exhibits/mainframe/

mainframe_PP1401.html (accessed June 7, 2010)

22. Agenda, a meeting of the executive committee of IBM World Trade Corporation. New York, February 24, 1969. World Trade Corporation, office of the secretary, board of directors, box 16. IBM Archive, Somers, New York (unpublished)

23. Välitöntä tunnelmaa Järfällassa. (Unreserved feeling in Järfälla, in Finnish.) (No author, presumably Katri Kettunen) Suomen IBM uutiset, 6(3), 10-11 (1971)

24. Petersson, T.: Facit and the BESK Boys: Sweden's Computer Industry (1956-1962). IEEE Annals of the History of Computing 27(4), 23-30 (2005)

25. Winberg, A.: Suomen IBM:n harjoittama alihankintatoiminta (Subcontracting activity coordinated by IBM Finland, in Finnish). IBM Katsaus 15(3), 48-49 (1976)

26. Email letter from Sverrir 'Olafsson to Petri Paju (November 2, 2010)

27. Suomen IBM 1969. Vuosiraportti. (Yearly report of IBM Finland in 1969, in Finnish.) IBM Finland, Helsinki (1969)

28. Suomalaista uusvientiä. (New Finnish export, in Finnish.) (No author, presumably Katri Kettunen.) IBM uutiset, 7(2), 1 (1972)

29. Lahti, S., Lehtinen, J. (eds.): Suomen ATK-tuotannon vuosikirja 1979. (Yearbook for ADP production in Finland.) Raportti n:o 53. VTT, ATK-palvelutoimisto, Espoo (1979)

30. Lavonen, P.: Radiopajoista matkapuhelinteollisuuteen. Salon elektroniikkateollisuuden historia 1925-2005 (From radio workshops to mobile phone industry. History of the electronics industry in the town of Salo 1925-2005, in Finnish). Town of Salo, Salo (2005)

31. Paju, P.: National Projects and International Users: Finland and Early European computerization. IEEE Annals of the History of Computing 30(4), 77-91 (2008)

32. World Computer Census as of December, 1966 (Digital comp. systems), from Computers and Automation for January 1967. (Translated into Finnish.) ATK:n Tieto-Sanomat 2 (4) 31 (1967)

33. Johansson, M.: Smart, Fast and Beautiful. On Rhetoric of Technology and Computing Discourse in Sweden 1955-1995. Linköping Studies in Arts and Science 164. Linköping University, Linköping (1997)

34. Lindegren, O.: IBM Nordic Education Center - Lidingö. ATK:n Tieto-Sanomat 5(1), 12-13 (1970) 